\title{
Incidence of Injuries in Athletes of Olympic Wrestling
}

\author{
Sérgio Luiz Carlos Dos Santos*, Kelly Nunes, Michele Nunes and Natália Rios \\ Department of Physical Education, Brazil
}

Received: 眥: November 29, 2018; Published: 制: December 03, 2018

*Corresponding author: Sérgio Luiz Carlos Dos Santos, Department of Physical Education, Brazil

\begin{abstract}
This study aims to present, through a literature survey, the incidence of injuries in wrestling in order to characterize them in relation to their location (upper or lower limbs), type (fractures, dislocations, sprains, injuries tendinitis and muscle), increased susceptibility period (period of training or competition) and practice time mode. Thus, we conclude that the lesions occur in Olympic wrestling in the lower extremities, the anatomical regions of the knee, shoulder, thigh and ankle, primarily sprains, muscle injuries and bruises and that usually occur with more experienced athletes.

Keywords: Wrestling; Injuries in Sports; Injuries in Wrestling
\end{abstract}

\section{Introduction}

The Olympic wrestling is contact sport and high intensity, with a pause between these thirty second periods and the maximum time to recover from any injury during combat is two minutes [1]. Because it is a contact modality its practice is related to a high incidence of orthopedic injuries. Injuries often occur at important points in the career, leading to withdrawal from competitions, participation of selections, and may even lead to career withdrawal. In the Olympic Wrestling, according to Garnés Roz, Gomez \& Ignoto [1], the knee is one of the most injured joints during combat, followed by the shoulder joint. The same author, in another study, says that musculoskeletal injuries are especially common in the lower limbs, specifically the knee. These results are also found in the studies conducted by elite Brazilian athletes [2], where $85 \%$ of athletes suffered at least one injury, mostly in the lower limb, mainly knee, followed by shoulder injuries, thigh and ankle. The knowledge of the main injuries that occur in the Olympic Wrestling is necessary so that the professionals involved with this sport can elaborate a suitable training program and adopt measures that prevent the injuries without this diminishing the performance of the athletes.

\section{Methodology}

This research is a review of the literature, of the descriptive type, carried out through bibliographical research, obtained through the Lilacs and Scielo databases. The descriptors used to search the articles were: Olympic wrestling, sports injuries, and injuries in the Olympic wrestling. Regarding the recovery of the lesions presented by the athletes in this study, those who were treated conservatively had a period of remission of the practices of 1.6 months, while the lesions that required surgical treatment had a period of 7 months. These injuries are also associated to the practice time of the modality, as pointed out in this study where the athletes who had less than 24 months of practice had not suffered injuries and that the athletes with the longest practice had a higher number of injuries. And with regard to the period, in which these injuries occur, most injuries occur during training and the incidence of injury from exposure is about four times higher during competitions. In other words, the Olympic fight presents high injury rates, being considered the second sport with the highest number of injuries, behind only American football, according to Jarrett [3]. In addition to the injuries presented above, another study showed the occurrence of low back pain, spinal curvatures and shortening of the major muscles that control pelvic tilt in Olympic wrestling athletes. According to this study of Dezan [4], during the practice of the Olympic Wrestling, the requirement of a great strength and power of the hip flexors muscles of the athletes is visible, since many hip flexion movements are performed, with the intention to increase stability during defense, since the athlete has his center of mass lowered. However, such frequent movements become detrimental to the spine, as an overload occurs in the functional units of the spine. In the study by Dezan [4], with 12 elite male athletes, aged 23 years, stature between $1.71 \mathrm{~m}$ and the weight in the $74 \mathrm{~kg}$ range, all participants of the First Brazilian Olympic Wrestling Championship, held in Curitiba in 2001, as a training routine, approximately 10.5 hours / week; it was verified that $58.3 \%$ of the athletes presented low back pain, where $71.4 \%$ 
reported chronic symptoms of low back pain and $28.6 \%$ acute pain. In addition, it was verified that athletes with chronic low back pain had a shorter shortening of the one and bi-articular flexors, of the hip and greater flexibility of the ischial-tibial muscles. It can be seen that reports of lumbar pain in athletes are frequent, and possibly related to postural alterations such as lumbar lordosis, because Dezan [4] confirm that athletes with low back pain also presented a greater angle of lumbar curvature, that is, lordosis. In addition, it is concluded that these back pains would also be related to the great muscular imbalance between the hip flexor musculature and the ischio-tibial musculature [5].

\section{Final Considerations}

From this reflection we can conclude that the majority of the athletes of Olympic fight have already presented some injury due to the practice of the modality and that the athletes with greater time of practice are more susceptible to these injuries. In addition, we can characterize Olympic wrestling injuries as having a higher incidence in lower limbs, more frequent involvement of the knee, shoulder, thigh and ankle anatomical regions, with the most frequent diagnoses being sprains, muscle injuries and bruises.

That is, the Olympic fight, as a contact sport and high intensity, requires a good physical training of the athlete to avoid subsequent

ISSN: 2574-1241

DOI: 10.26717/BJSTR.2018.11.002137

Sérgio Luiz Carlos Dos Santos. Biomed J Sci \& Tech Res

This work is licensed under Creative Commons Attribution 4.0 License

Submission Link: https://biomedres.us/submit-manuscript.php injuries. This physical preparation should involve muscular strength, flexibility and a good development of the joint. In addition, there is a need to balance these valences between muscle groups, especially between the extensor muscle of the hip and the ischiostibial muscles, in order to reduce the incidence of back pain and postural changes in these athletes. That is, it is necessary for both muscles to be strong and flexible.

\section{References}

1. Garnés Ros AF, Gómez BB, Ignoto JR (2005) Luta olímpica: lesões mais frequentes. Garnés Ros AF, Ignoto JR, García JCL, Abellán AM (Eds.); Lesões musculares na luta e sua relação com as técnicas de luta. Revista Digital Efdeportes. Ano 10. $\mathrm{N}^{\circ}$ 80. Janeiro.

2. Barroso BG, Silva JMA, Garcia AC, Ramos NCO, Martinelli MO, et al. (2011) Lesões musculoesqueléticas em atletas de luta olímpica. Acta Ortop Bras 19(2): 98-101.

3. Jarrett GJ, Orwin JF, Dick RW (1998) Injuries in collegiate wrestling. Am VJ Sports Med 26(5): 674-680.

4. Dezan VH, Sarraf TA, Rodacki ALF (2004) Alterações posturais, desequilíbrios musculares e lombalgias em atletas de luta olímpica. $\mathrm{R}$ Bras Ciência e Movimento 12(1): 35-38.

5. Filho (2009) Lesões esportivas durante lutas no boxe amador. Arquivos Brasileiros de Ciências da Saúde 35(1): 15-18.

$\begin{array}{ll}\text { BIOMEDICAL } & \text { Assets of Publishing with us } \\ \text { RESEARCHES } & \text { - Global archiving of articles } \\ & \text { - Immediate, unrestricted online access } \\ & \text { - Rigorous Peer Review Process } \\ \end{array}$

